\title{
DETERMINATION OF SILICON AND CHROMIUM IN GOLD MATRIX USING PROTON INDUCED X-RAY EMISSION
}

\author{
Daniel D. ${ }^{1}$ and Bello A. ${ }^{2}$ \\ ${ }^{1}$ Department of Physics, Kebbi State Government Girls Science College Riba. Email: \\ danny44phy@gmail.com \\ ${ }^{2}$ Department of Physics, Kebbi State University of Science and Technology Aliero. Email: \\ bello.abdullahi455@gmail.com
}

Cite this article:

Daniel D., Bello A. (2021), Determination of Silicon and Chromium in Gold Matrix Using Proton Induced X-Ray Emission. African Journal of Environment and Natural Science Research 4(4), 1-10. DOI: 10.52589/AJENSRBPQ5D6XD.

\section{Manuscript History}

Received: 11 July 2021

Accepted: 3 Aug 2021

Published: 17 Aug 2021

Copyright $\odot 2020$ The Author(s)

This is an Open Access article distributed under the terms of Creative Commons AttributionNonCommercial-NoDerivatives 4.0 International (CC BY-NC-ND 4.0 ), which permits anyone to share, use, reproduce and redistribute in any medium, provided the original author and source are credited.

\begin{abstract}
The research aimed at the determination of elemental concentrations of silicon and chromium in five geological samples at the mining site of Garin Awwal area using the method of PIXE for analyses. The choice PIXE method in this research was due to its high sensitivity and multi-element capability that analyzes any element from sodium to uranium in a single spectrum. PIXE technique of $2.5 \mathrm{MeV}$ proton beam was used to characterize five samples. Samples were irradiated and analyzed at Centre for Energy Research and Development, IleIfe, Osun State, Nigeria. From the Spectra and results generated, silicon and chromium are of commercial deposit in the area, alongside other elements such as Iron $(\mathrm{Fe})$, Magnesium $(\mathrm{Mg})$ and Aluminium(Al) which appear to be deposited in commercial quantities in the area.
\end{abstract}

KEYWORDS: PIXE, CERD and Silicon and Chromium 


\section{INTRODUCTION}

Silicon and Chromium are generallynatural components of the Earth's crust and therefore are majorconstituents of soil. It may not be easy to assign a definite causefor an increase in metal content of a soil sample without recourseto the background level of the metal (Wilberforce $e t$ al 2012). Silicon is an element of earth, it is available, abundantly on earth's crust. Itoccurs to the tune of $27.7 \%$ in the earth's crust. Silicon rarelyappears as an integral component of biological materials. Thepresence of silicon in plants, animals and humans plays apositive role (Vasanthiet al, 2012). Therefore, its requirement toanimals and humans becomes important for the development of bone, fairness of hair and also prevention of certaincardiovascular diseases even though it is a serious health hazardcausing silicosis of lungs upon inhalation (Vasanthiet al, 2012). Yet silicon products have emerged for use in food, cosmeticsand computers which men and women use in day today life (Vasanthiet al, 2012). Chromium is a relativelycommon element with an average concentration of 100ppm. It is the $21^{\text {st }}$ most commonly occurring element inthe earth's crust. Chromium compounds are used in thechemical industry in various fields. The metal industry uses most of the chromium in the form of master alloys, preferably in special steels (stainless steel). Additional applications of chromium compounds are found in the following: building industry (aspigments), printing industry (photomechanical reproduction processes), oil industry (as anti corrosives), textileindustry (chromium mordant for textiles and chrome dyeing processes), match industry and fireworks (additiveto the inflammable mixture). In the cassette tape industry chromium oxide is used in a specially crystallized form (Bello et al, 2012).

Thisresearch aimed at the determination of elemental concentrations of silicon and chromium in goldmatrix at the mining site of Garin Awwal area. The GarinAwwal was chosen tobe the study area of this research due to the availability of the sample of interest at Garin Awwal mining station located in Fakai. The choice of PIXE method in this research was due to its high sensitivity and multi-element capability thatanalyzes any element from sodium to uranium in a single spectrum (Hasnat, 2007). When charged particles collide with atoms, atomic inner shell electrons become ionized, producing characteristic X-rays. This phenomenon is called particle-induced X-ray emission (PIXE). The word PIXE is an acronym that stands for Particle or Proton Induced X-rays Emission. PIXE was first experimentally shown by Sven A.E. Johansson of Lund Institute of Science and Technology in 1970. PIXE is non-destructive. Therefore, the samples are not destroyed or consumed in the analysis. The sample is still available to be characterized by other methods. In PIXE technique, the accelerated proton beam is used due to its low bremsstrahlung radiations, high fluorescence yield and X-rays production cross-section. As a trace elemental analytical technique PIXE is very powerful with minimum detection limits (MDL) between 0.1 and 50ppm depending on the element and host matrix Johansson et al., (1995).

PIXE analysis consists of two parts. The first is to identify the atomic species in the target from the energies of the characteristic peaks in the X-ray emission spectrum and the second part is to determine the amount of a particular element present in the target from the intensity of its characteristic X-ray emission spectrum. This normally requires knowledge of the ionisation cross-sections, fluorescence yields and absorption coefficients. Depth profile analysis may be performed if the PIXE is combined with other methods like Rutherford Back Scattering (RBS) and/or sample etching techniques Govil, (2001). Trace elements play very important roles in living beings. Any fluctuation like deficiency or excess in their normal 
level in living cells may lead to physiological disorders causing various diseases like hypertension, dental caries, goitre, cancer, heart disease, gallstones, obesity, and anemia (Buhari, 2018).

\section{MATERIAL AND METHOD}

\section{Materials}

The total of five samples was collected at places where gold mining were been undertaken, Global Positioning System (GPS), Mechanical Crusher, Chemflex TM, Electric Shaker, Aluminium Foil Paper and GUPIX Software.

\section{Study Area}

The site is located at approximately latitudes 007008.690'E and longitudes $09034^{\prime} 224^{\prime}$ 'N in Fakai local Government Area, Kebbi State, Nigeria. Where samples are being collected, It is North to Sokoto State, East to DankoWasagu L.G.A, South to Niger State and West to Koko Besse L.G.A.

\section{Sample collection and Preparation}

The geological samples (gold matrix) were collected from five different locations of Garin Awwal mining area. PIXE requires little orminimal sample preparations, therefore care must be taken inhandling the material to be analyzed (Ezeh et al, 2017). Eachsample collectedwas crushed to small pieces using mechanicalcrusher. The crushed samples were dried at $105^{\circ} \mathrm{C}$ to constantweight (Abdullahi, 2012). The dried samples were ground toform fine powder. Then the powdered samples were sievedusing a standard set of sieves to a diameter range of less than $125 \mu \mathrm{m}$ (Buhari, 2018). Every powdered sample was shaken using an electric shaker to be sure that the sample was homogenized. The samples (leftover) were mixed with binding agent such as chemflex TM (Buhari, 2018).Five pellets are made of $13 \mathrm{~mm}$ diameter and about 1mmthickness (Rahman et al, 2016) and thereafter fastened to thespecimen holder (Abdullahi 2012). The aluminium foil paper is placed behind the pellets before it is fastened to the special ladder to avoid the masking tape sticking to the pellets. It is thenmeticulously lowered into the specimen chamber. Once the specimen is securely placed in the specimen chamber, the chamber is made vacuous by a special vacuum pump affixed tothe chamber (Abdullahi, 2012).

\section{Irradiation of samples}

The samples were irradiated using $2.5 \mathrm{MeV}$ tandem accelerator at the Centre for Energy Research and Development (CERD), ObafemiAwolowo University (OAU) Ile-Ife, OsunState, Nigeria (Buhari, 2018). The target was placed at an angle of $45^{\circ}$ with respect to the proton beam from the accelerator (Arifet al, 2016). Each sample is irradiated and counted (for $10 \mathrm{~min}$ ). Subsequently, the spectrum obtain is stored for qualitative and quantitative calculation at a later date. Irradiation is done together with Standard Reference Material (SRM) for relative quantitative calculation and quality control. The precision and trueness of the method were checked by analyzing the two SRMs under the same experimental condition as the samples. 


\section{RESULTS AND DISCUSSION}

\section{Quality Control}

Table 3.1 shows the results of irradiation carried out on standard (NIST) 278 (Obsidian Rock). The table contains the analyte, standard and certain values. The observation from the table reveals that the certain values of the analyte silicon $(\mathrm{Si})$, potassium $(\mathrm{K})$, iron $(\mathrm{Fe})$ and rubidium $(\mathrm{Rb})$ respectively are of the standard. Analyte chlorine $(\mathrm{Cl})$, vanadium $(\mathrm{V})$ and zirconium (Zr) respectively are below the standard. Observation shows that PIXE is efficient for the analysis.

Table 3.1 (NIST) 278 (Obsidian Rock)

\begin{tabular}{ccc}
\hline ANALYTE & STANDARD & CERT. VALUES (ppm) \\
\hline $\mathrm{Si}$ & $341397.3 \pm 6281.71$ & 341436 \\
$\mathrm{Cl}$ & $584.5 \pm 88.03$ & - \\
$\mathrm{K}$ & $34511.7 \pm 106.99$ & 34530 \\
$\mathrm{Ca}$ & $7020.8 \pm 90.57$ & 7026 \\
$\mathrm{Ti}$ & $1439.7 \pm 22.75$ & 1469 \\
$\mathrm{~V}$ & $30.7 \pm 15.76$ & - \\
$\mathrm{Mn}$ & $401.2 \pm 10.99$ & 403 \\
$\mathrm{Fe}$ & $14275.1 \pm 51.39$ & 14268 \\
$\mathrm{Cu}$ & $6.8 \pm 3.02$ & 5.9 \\
$\mathrm{Zn}$ & $55.8 \pm 5.96$ & 55 \\
$\mathrm{Rb}$ & $127.5 \pm 18.47$ & 127.5 \\
$\mathrm{Sr}$ & $64.2 \pm 13.67$ & .5 \\
$\mathrm{Zr}$ & $375.8 \pm 39.46$ & - \\
$\mathrm{Ba}$ & $1222.2 \pm 165.49$ & 1140 \\
$\mathrm{Ce}$ & $67.1 \pm 42.94$ & 62.2 \\
\hline
\end{tabular}


African Journal of Environment and Natural Science Research

ISSN: 2689-9434

Volume 4, Issue 4, 2021 (pp. 1-10)

www.abjournals.org

Table 3.2 Average Concentration (ppm) of Elements in Sample A

\begin{tabular}{|c|c|c|c|}
\hline Element & Oxide & $\begin{array}{l}\text { Element Concentration } \\
\text { (ppm) }\end{array}$ & $\begin{array}{l}\text { Oxide Concentration } \\
\text { (ppm) }\end{array}$ \\
\hline $\mathrm{Pb}$ & $\mathrm{PbO}$ & 756 & 814 \\
\hline $\mathrm{Na}$ & $\mathrm{Na}_{2} \mathrm{O}$ & 3503 & 4723 \\
\hline $\mathrm{Mg}$ & $\mathrm{MgO}$ & 2660 & 4411 \\
\hline $\mathrm{Al}$ & $\mathrm{Al}_{2} \mathrm{O}_{3}$ & 46037 & 86985 \\
\hline $\mathrm{Si}$ & $\mathrm{SiO}_{2}$ & 401090 & 858058 \\
\hline $\mathrm{P}$ & $\mathrm{P}_{2} \mathrm{O}_{5}$ & 714 & 1637 \\
\hline $\mathrm{S}$ & $\mathrm{SO}_{3}$ & 78481 & 195964 \\
\hline $\mathrm{K}$ & $\mathrm{K}_{2} \mathrm{O}$ & 25060 & 30186 \\
\hline $\mathrm{Ti}$ & $\mathrm{TiO}_{2}$ & 533 & 889 \\
\hline $\mathrm{V}$ & $\mathrm{V}_{2} \mathrm{O}_{3}$ & 61 & 90 \\
\hline $\mathrm{Cr}$ & $\mathrm{Cr}_{2} \mathrm{O}_{3}$ & 538 & 787 \\
\hline Mn & $\mathrm{MnO}$ & 137 & 177 \\
\hline $\mathrm{Fe}$ & $\mathrm{FeO}$ & 90510 & 116440 \\
\hline $\mathrm{Ni}$ & $\mathrm{NiO}$ & 14 & 18 \\
\hline $\mathrm{Cu}$ & $\mathrm{Cu}_{2} \mathrm{O}$ & 35 & 39 \\
\hline $\mathrm{Zn}$ & $\mathrm{ZnO}$ & 351 & 436 \\
\hline $\mathrm{Se}$ & $\mathrm{SeO}_{2}$ & 64 & 91 \\
\hline $\mathrm{Br}$ & $\mathrm{Br}$ & 153 & 153 \\
\hline $\mathrm{Rb}$ & $\mathrm{Rb}_{2} \mathrm{O}$ & 123 & 135 \\
\hline $\mathrm{Y}$ & $\mathrm{Y}_{2} \mathrm{O}_{3}$ & 65 & 82 \\
\hline $\mathrm{Zr}$ & $\mathrm{ZrO}_{2}$ & 117 & 158 \\
\hline $\mathrm{Ba}$ & $\mathrm{BaO}$ & 807 & 901 \\
\hline Dy & $\mathrm{Dy}_{2} \mathrm{O}_{3}$ & 2309 & 2650 \\
\hline $\mathrm{Au}$ & $\mathrm{Au}_{2} \mathrm{O}_{3}$ & 457 & 513 \\
\hline $\mathrm{Bi}$ & $\mathrm{Bi}_{2} \mathrm{O}_{3}$ & 151 & 168 \\
\hline Th & $\mathrm{ThO}_{2}$ & 357 & 406 \\
\hline $\mathrm{U}$ & $\mathrm{UO}_{3}$ & 702 & 843 \\
\hline
\end{tabular}


African Journal of Environment and Natural Science Research

ISSN: 2689-9434

Volume 4, Issue 4, 2021 (pp. 1-10)

www.abjournals.org

Table 3.3 Average Concentration (ppm) of Elements in Sample B

\begin{tabular}{|c|c|c|c|}
\hline Element & Oxide & $\begin{array}{c}\begin{array}{c}\text { Element } \\
\text { Concentration } \\
(\mathrm{ppm})\end{array} \\
\end{array}$ & $\begin{array}{c}\text { Oxide Concentration } \\
(\text { ppm) }\end{array}$ \\
\hline $\mathrm{Pb}$ & $\mathrm{PbO}$ & 2390 & 2575 \\
\hline $\mathrm{Na}$ & $\mathrm{Na}_{2} \mathrm{O}$ & 57 & 77 \\
\hline $\mathrm{Mg}$ & $\mathrm{MgO}$ & 545 & 904 \\
\hline $\mathrm{Al}$ & $\mathrm{Al}_{2} \mathrm{O}_{3}$ & 7254 & 13706 \\
\hline $\mathrm{Si}$ & $\mathrm{SiO}_{2}$ & 73577 & 157404 \\
\hline S & $\mathrm{SO}_{3}$ & 253510 & 633001 \\
\hline $\mathrm{K}$ & $\mathrm{K}_{2} \mathrm{O}$ & 2492 & 3002 \\
\hline $\mathrm{Ca}$ & $\mathrm{CaO}$ & 200 & 280 \\
\hline $\mathrm{Ti}$ & $\mathrm{TiO}_{2}$ & 394 & 657 \\
\hline $\mathrm{Cr}$ & $\mathrm{Cr}_{2} \mathrm{O}_{3}$ & 231 & 338 \\
\hline $\mathrm{Mn}$ & $\mathrm{MnO}$ & 74 & 95 \\
\hline $\mathrm{Fe}$ & $\mathrm{FeO}$ & 267407 & 344015 \\
\hline $\mathrm{Ni}$ & $\mathrm{NiO}$ & 81 & 103 \\
\hline $\mathrm{Cu}$ & $\mathrm{Cu}_{2} \mathrm{O}$ & 24 & 27 \\
\hline $\mathrm{Zn}$ & $\mathrm{ZnO}$ & 2880 & 3585 \\
\hline $\mathrm{Se}$ & $\mathrm{SeO}_{2}$ & 396 & 556 \\
\hline $\mathrm{Rb}$ & $\mathrm{Rb}_{2} \mathrm{O}$ & 240 & 263 \\
\hline $\mathrm{Sr}$ & $\mathrm{SrO}$ & 26 & 31 \\
\hline Dy & $\mathrm{Dy}_{2} \mathrm{O}_{3}$ & 12356 & 14181 \\
\hline $\mathrm{Au}$ & $\mathrm{Au}_{2} \mathrm{O}_{3}$ & 1579 & 1771 \\
\hline $\mathrm{Bi}$ & $\mathrm{Bi}_{2} \mathrm{O}_{3}$ & 652 & 726 \\
\hline $\mathrm{U}$ & $\mathrm{UO}_{3}$ & 56 & 67 \\
\hline
\end{tabular}


African Journal of Environment and Natural Science Research

ISSN: 2689-9434

Volume 4, Issue 4, 2021 (pp. 1-10)

www.abjournals.org

Table 3.4 Average Concentration (ppm) of Elements in Sample C

\begin{tabular}{|c|c|c|c|}
\hline Element & Oxide & $\begin{array}{c}\text { Element } \\
\text { Concentration } \\
(\mathbf{p p m})\end{array}$ & $\begin{array}{c}\text { Oxide Concentration } \\
(\text { ppm) }\end{array}$ \\
\hline $\mathrm{Pb}$ & $\mathrm{PbO}$ & 309 & 333 \\
\hline $\mathrm{Na}$ & $\mathrm{Na}_{2} \mathrm{O}$ & 537 & 724 \\
\hline $\mathrm{Mg}$ & $\mathrm{MgO}$ & 49749 & 82488 \\
\hline $\mathrm{Al}$ & $\mathrm{Al}_{2} \mathrm{O}_{3}$ & 87232 & 164823 \\
\hline $\mathrm{Si}$ & $\mathrm{SiO}_{2}$ & 242029 & 517776 \\
\hline $\mathrm{P}$ & $\mathrm{P}_{2} \mathrm{O}_{5}$ & 1517 & 3476 \\
\hline $\mathrm{Cl}$ & $\mathrm{Cl}$ & 334 & 334 \\
\hline $\mathrm{K}$ & $\mathrm{K}_{2} \mathrm{O}$ & 53960 & 64999 \\
\hline $\mathrm{Ca}$ & $\mathrm{CaO}$ & 35294 & 49382 \\
\hline $\mathrm{Ti}$ & $\mathrm{TiO}_{2}$ & 18844 & 31432 \\
\hline $\mathrm{V}$ & $\mathrm{V}_{2} \mathrm{O}_{3}$ & 493 & 725 \\
\hline $\mathrm{Cr}$ & $\mathrm{Cr}_{2} \mathrm{O}_{3}$ & 335 & 490 \\
\hline Mn & $\mathrm{MnO}$ & 1772 & 2288 \\
\hline $\mathrm{Fe}$ & $\mathrm{FeO}$ & 141279 & 181753 \\
\hline $\mathrm{Cu}$ & $\mathrm{Cu}_{2} \mathrm{O}$ & 41 & 46 \\
\hline $\mathrm{Zn}$ & $\mathrm{ZnO}$ & 580 & 722 \\
\hline $\mathrm{Br}$ & $\mathrm{Br}$ & 62 & 62 \\
\hline $\mathrm{Rb}$ & $\mathrm{Rb}_{2} \mathrm{O}$ & 278 & 304 \\
\hline $\mathrm{Sr}$ & $\mathrm{SrO}$ & 195 & 231 \\
\hline $\mathrm{Zr}$ & $\mathrm{ZrO}_{2}$ & 53 & 71 \\
\hline $\mathrm{Nb}$ & $\mathrm{Nb}_{2} \mathrm{O}_{5}$ & 219 & 314 \\
\hline Mo & $\mathrm{MoO}_{3}$ & 2682 & 4024 \\
\hline Dy & $\mathrm{Dy}_{2} \mathrm{O}_{3}$ & 354 & 406 \\
\hline $\mathrm{Au}$ & $\mathrm{Au}_{2} \mathrm{O}_{3}$ & 254 & 285 \\
\hline
\end{tabular}


African Journal of Environment and Natural Science Research

ISSN: 2689-9434

Volume 4, Issue 4, 2021 (pp. 1-10)

www.abjournals.org

Table 3.5 Average Concentration (ppm) of Elements in Sample D

\begin{tabular}{|c|c|c|c|}
\hline Element & Oxide & $\begin{array}{c}\begin{array}{c}\text { Element } \\
\text { Concentration } \\
(\mathbf{p p m})\end{array} \\
\end{array}$ & $\begin{array}{c}\text { Oxide Concentration } \\
(\mathbf{p p m})\end{array}$ \\
\hline $\mathrm{Pb}$ & $\mathrm{PbO}$ & 588 & 633 \\
\hline $\mathrm{Na}$ & $\mathrm{Na}_{2} \mathrm{O}$ & 281 & 378 \\
\hline $\mathrm{Mg}$ & $\mathrm{MgO}$ & 795 & 1319 \\
\hline $\mathrm{Al}$ & $\mathrm{Al}_{2} \mathrm{O}_{3}$ & 9468 & 17890 \\
\hline $\mathrm{Si}$ & $\mathrm{SiO}_{2}$ & 434689 & 929936 \\
\hline $\mathrm{P}$ & $\mathrm{P}_{2} \mathrm{O}_{5}$ & 601 & 1378 \\
\hline S & $\mathrm{SO}_{3}$ & 5471 & 13662 \\
\hline $\mathrm{K}$ & $\mathrm{K}_{2} \mathrm{O}$ & 4127 & 4971 \\
\hline $\mathrm{Ca}$ & $\mathrm{CaO}$ & 97 & 136 \\
\hline $\mathrm{Ti}$ & $\mathrm{TiO}_{2}$ & 243 & 405 \\
\hline $\mathrm{V}$ & $\mathrm{V}_{2} \mathrm{O}_{3}$ & 17 & 25 \\
\hline $\mathrm{Cr}$ & $\mathrm{Cr}_{2} \mathrm{O}_{3}$ & 1371 & 2004 \\
\hline $\mathrm{Mn}$ & $\mathrm{MnO}$ & 66 & 86 \\
\hline $\mathrm{Fe}$ & $\mathrm{FeO}$ & 18284 & 23522 \\
\hline $\mathrm{Ni}$ & $\mathrm{NiO}$ & 3 & 4 \\
\hline $\mathrm{Cu}$ & $\mathrm{Cu}_{2} \mathrm{O}$ & 6 & 7 \\
\hline $\mathrm{Zn}$ & $\mathrm{ZnO}$ & 85 & 106 \\
\hline $\mathrm{Se}$ & $\mathrm{SeO}_{2}$ & 56 & 79 \\
\hline $\mathrm{Br}$ & $\mathrm{Br}$ & 68 & 68 \\
\hline $\mathrm{Rb}$ & $\mathrm{Rb}_{2} \mathrm{O}$ & 22 & 24 \\
\hline $\mathrm{Sr}$ & $\mathrm{SrO}$ & 32 & 37 \\
\hline $\mathrm{Y}$ & $\mathrm{Y}_{2} \mathrm{O}_{3}$ & 65 & 82 \\
\hline $\mathrm{Sn}$ & $\mathrm{SnO}_{2}$ & 2220 & 2819 \\
\hline $\mathrm{Au}$ & $\mathrm{Au}_{2} \mathrm{O}_{3}$ & 42 & 47 \\
\hline Th & $\mathrm{ThO}_{2}$ & 467 & 532 \\
\hline $\mathrm{U}$ & $\mathrm{UO}_{3}$ & 53 & 63 \\
\hline
\end{tabular}


Table 3.6 Average Concentration (ppm) of Elements in Sample E

\begin{tabular}{|c|c|c|c|}
\hline Element & Oxide & $\begin{array}{c}\text { Element } \\
\text { Concentration } \\
(\text { ppm) }\end{array}$ & $\begin{array}{c}\text { Oxide Concentration } \\
(\text { ppm) }\end{array}$ \\
\hline $\mathrm{Na}$ & $\mathrm{Na}_{2} \mathrm{O}$ & 519 & 700 \\
\hline $\mathrm{Mg}$ & $\mathrm{MgO}$ & 535 & 886 \\
\hline $\mathrm{Al}$ & $\mathrm{Al}_{2} \mathrm{O}_{3}$ & 12748 & 24087 \\
\hline $\mathrm{Si}$ & $\mathrm{SiO}_{2}$ & 510806 & 1092775 \\
\hline $\mathrm{P}$ & $\mathrm{P}_{2} \mathrm{O}_{5}$ & 620 & 1422 \\
\hline K & $\mathrm{K}_{2} \mathrm{O}$ & 2312 & 2785 \\
\hline $\mathrm{Sc}$ & $\mathrm{Sc}_{2} \mathrm{O}_{3}$ & 24 & 36 \\
\hline $\mathrm{Ti}$ & $\mathrm{TiO}_{2}$ & 426 & 710 \\
\hline $\mathrm{Cr}$ & $\mathrm{Cr}_{2} \mathrm{O}_{3}$ & 728 & 1064 \\
\hline Mn & $\mathrm{MnO}$ & 59 & 76 \\
\hline $\mathrm{Fe}$ & $\mathrm{FeO}$ & 10638 & 13685 \\
\hline $\mathrm{Ni}$ & $\mathrm{NiO}$ & 4 & 5 \\
\hline $\mathrm{Cu}$ & $\mathrm{Cu}_{2} \mathrm{O}$ & 5 & 6 \\
\hline As & $\mathrm{As}_{2} \mathrm{O}_{5}$ & 35 & 54 \\
\hline $\mathrm{Br}$ & $\mathrm{Br}$ & 19 & 19 \\
\hline $\mathrm{Rb}$ & $\mathrm{Rb}_{2} \mathrm{O}$ & 66 & 72 \\
\hline $\mathrm{Sr}$ & $\mathrm{SrO}$ & 52 & 62 \\
\hline Y & $\mathrm{Y}_{2} \mathrm{O}_{3}$ & 41 & 52 \\
\hline $\mathrm{Sn}$ & $\mathrm{SnO}_{2}$ & 6766 & 8591 \\
\hline Dy & $\mathrm{Dy}_{2} \mathrm{O}_{3}$ & 1047 & 1201 \\
\hline $\mathrm{Au}$ & $\mathrm{Au}_{2} \mathrm{O}_{3}$ & 64 & 72 \\
\hline
\end{tabular}

Among the five samples analyzed, it was observed that silicon ( $\mathrm{Si}$ ) has the highest element concentration in sample A, C, D and E to be 401090ppm, 242029ppm, 434689ppm and 510806ppm. Chromium (Cr) has high element concentration which is above the world health recommendation of $100 \mathrm{ppm}$ in sample $\mathrm{A}, \mathrm{B}, \mathrm{C}, \mathrm{D}$ and $\mathrm{E}$ to be 538ppm, 231ppm, 335ppm, $1371 \mathrm{ppm}$ and $728 \mathrm{ppm}$ respectively. All the samples in the study area indicated high deposit of Iron (Fe),Magnesium(Mg) and Aluminium(Al). 


\section{CONCLUSION}

From the obtained results, it appears that PIXE can provide useful data with a satisfactory accuracy and precision. The analysis of data obtained from five samples using PIXE shows that silicon and chromium are of commercial deposit in the area, alongside with the other elements such as Iron (Fe), Magnesium $(\mathrm{Mg}$ ) and Aluminium (Al) which appear to be deposited in commercial quantities in the area.

\section{REFERENCE}

Abdullahi B (2012) "The Determination of Zirconium fromNorth-Western Nigeria using PIXE Technique" InternationalJournal of Science and Technology, Volume 2 No.9, PP (613-617)

Arif R, Mohsin R, Nisar A, Athar N, Shahzad S, and ShahnawazM (2016) "Determination of trace elements in tap water usingpixe technique" Journal of Chemical and PharmaceuticalSciences, Volume 9 Issue 1, PP (34 -38)

Bello A, M. T. Tsepav1, M. D. Oladipupo1 \& B. Alfa, (2012). Determination of Chromium and Other Trace Elements from North Western Nigeria by Proton Induced X-ray Emission Technique. Modern Applied Science; Vol. 6, No. 7

Buhari S, (2018).Determination of Lead from Tailings of Gold Matrix using Proton Induced $X$-ray Emission International Journal of Science and Research (IJSR) Vol. 8, Issue 1, pp110-112.

Ezeh G \&Obiajunwa I (2017) "Multi-elemental analysis of colonial and post- colonial Nigerian coins by proton induced $x$-rayemission spectrometry" Journal of Fundamental andApplied Sciences, 9(1), 499-508

Govil I. M, (2001). Department of Physics, Panjab University, Chandigarh 160014, India. Current Science, Vol.80, No.12. pp1-8, June

HasnatMdKabir (2007) "Particle Induced X-ray Emission(PIXE) Setup and Quantitative Elemental Analysis" Adissertation submitted to Kochi University of Technology in partialfulfillment of the requirements for the degree of Doctorof Philosophy, Department of Electronic and Photonic SystemsEngineering Graduate School of Engineering Kochi Universityof Technology Kochi, Japan

Johansson S.A.E. Campbell, J.L and Malmqvist K.G, (1995). Particle Induced X-ray Emission spectrometry (PIXE) Wiley, Chichester, pp56-71

Rahman R, Rahman O, Shariff A, Uddin S, Hasan M, \&Shameem A (2016) "PIXE Analysis of Some EnvironmentalSamples from Selected Saline Region of (Bangladesh)" International Journal of Environmental Science andDevelopment, Vol. 7, No. 1, PP (16-21)

Vasanthi N, Lilly M. \& Anthoni S (2012) "Silicon in Day Today Life" World Applied Sciences Journal 17 (11), PP 1425-1440,published by IDOSI

Wilberforce O. J, Nwabue F \&Afiukwa J (2012) "Analysis of Heavy Metals in Soils of Enyigba and Abakaliki Using ProtonInduced X-Ray Emission (Pixe) Spectroscopy" Environment andPollution; Vol. 1, No. 2; Published by Canadian Center ofScience and Education. 